Tomasz Róg

Państwowa Wyższa Szkoła Zawodowa w Pile

tomaszrog@yahoo.co.uk

\title{
LANGUAGE AND CULTURE LEARNING STRATEGIES IN A STUDY ABROAD CONTEXT
}

\begin{abstract}
This article takes a step towards bridging the research gap between language-and-culture learning strategies and SLA-oriented outcomes of study abroad programmes. While studies concerning the impact of studying in foreign countries document various language-related benefits of the experience, only a handful addresses the types of language and culture learning strategies employed by study abroad participants. The present study tracks the use of these strategies by Polish students of English philology participating in a semester-long exchange programme in Portugal and Romania. It is revealed that although the use of language and culture learning strategies does not change significantly over the course of students' stay abroad, the strategies chosen before their departure are used rather consistently.
\end{abstract}

Keywords: language learning strategies, culture learning strategies, study abroad

Słowa kluczowe: strategie uczenia się języka, strategie uczenia się kultury, studia za granicą

\section{Introduction}

In the light of the growing popularity of study abroad (SA) programmes, there is a pressing need to better prepare their participants to be effective language and culture learners. This article addresses a research gap in studies on SA programmes by investigating various types of language and culture learning 
strategies employed by students of English as a foreign language during their stay abroad. The main assumption in this article is that a strategy-based approach to language and culture learning can greatly enhance SA participants' linguistic and intercultural gains. The very general nature of this approach, namely, its detachment from any specific language or culture, makes it a universal tool which can be used worldwide. Moreover, a strategy-based approach has the potential of creating more autonomous study abroad participants who can be effective cross-cultural mediators.

The types of language and culture learning strategies employed by SA participants are as yet little investigated in SLA research. In the study reported in this article, the author tracks the use of these strategies by Polish students of English philology taking part in a semester-long study abroad programme in Portugal and Romania. The changes in strategy use over time are also examined.

In the past decades, the concept of "strategy" has enjoyed great popularity in SLA research and has become a buzz word among language educators. Thus far, SLA research has revealed that the use of learning strategies helps make learning deeper, more effective and more enjoyable (Cohen and Macaro, 2007) and therefore can maximise the outcomes of learning (Gu, 2010). Most research on $\mathrm{L} 2$ learning strategies concerns reading skills and vocabulary acquisition (Swan, 2008), although attention has also been devoted to listening (Cross, 2011; Blyth, 2012; Rost and Wilson, 2013; Thorn, 2013) and grammar (Griffiths, 2008; Pawlak, 2011, 2013) learning strategies. It has also been documented that explicit strategy training has a considerable advantage over implicit instruction (Chamot, 2004). Furthermore, motivation has been proven to be strongly correlated to strategy use, as noted by Oxford (2011: 261): "if we want students to be strategic, they must be motivated". However, according to Gu (2010: 1), despite over thirty years of research theorists have not provided the necessary classroom applications needed both by teachers and learners.

With regards to SA contexts an even bigger gap can be identified. The existing research on strategy use among SA participants is remarkably scant. The literature available on the topic explicitly shows that use of language and culture learning strategies in study abroad contexts plays a key role in facilitating language gain and intercultural competence. However, the participants of various immersion programmes have been found to lack strategies for learning culture (Cohen et al., 2005) and not to be alert to the fact that simply having the experience of living abroad is not enough to develop their intercultural communication skills ( $M a$ et al., 2015). Therefore, one of the aims of the study presented below is to create a profile of language and culture learning strategies which would make a step towards improving our understanding of their use by SA students. 


\section{Language and culture learning strategies - overview}

Oxford and Schramm (2007: 47-48), researchers of language learning strategies (LLS), characterise these as a "specific plan, action, behaviour, step, or technique that individual learners use, with some degree of consciousness, to improve their progress in developing skills in a second or foreign language". In a more recent strategic self-regulation $\left(S^{2} R\right)$ model, Oxford (2011:12) stresses that LLS are teachable actions chosen by learners from various alternatives for the purposes of learning a second language. These are not to be confused with skills, which are automatic, whereas strategies are deliberate.

LLS have received much attention from SLA experts and teachers alike since they became popular in the 1980's and 1990's. It was asserted back then that success in language acquisition depends heavily on how learners employ LLS in specific contexts (Green and Oxford, 1995; Oxford and Ehrman, 1995). Currently, it is appreciated that LLS cannot substitute for hard work on the part of the teacher and that it is unrealistic to expect LLS to be a simple solution for classroom problems (Gu, 2010: 1-2). Nonetheless, LLS do make learning deeper, more long-lasting and more effective (Cohen and Macaro, 2007; Oxford, 2011).

Culture learning strategies can be defined as various behaviours and thoughts which are consciously undertaken in the process of learning about the ways in which cultures function and differ from each other and to respond to these differences. There are no existing models of culture learning strategies, although a very well-designed inventory of these strategies was developed in the field of applied linguistics by Paige et al. (2002). Oxford's self-regulation model for language learning includes Sociocultural-Interactive (SI) strategies, which "directly facilitate communication and deep understanding of the sociocultural context and one's role in it" (2011: 88). The use of culture learning strategies helps learners interact with other speakers of a foreign language, seek assistance in situations of communication breakdowns (e.g. when knowledge gaps arise) and to cope with issues of sociocultural power and identity.

The literature on language and culture learning strategies during study abroad is scant. Most research is dominated by studies examining the impact of overseas experience on language acquisition, the development of intercultural competence and the enhancement of participants' knowledge and skills. The limited attention given to the strategies used by SA participants to learn a foreign language or to discover a new culture makes it an interesting area yet to be studied. So far, researchers have agreed that language and culture learning strategies are defined as conscious and semi-conscious considerations, or actions, taken up by study abroad participants to improve the process of learning a foreign language, or to better understand the new culture (Cohen et al., 2005: 17; Ma et al., 2015: 108). 
In one of the earliest surveys, which involved over 130 British students taking part in SA in various European universities for a year, Ife (2000) discovered that LLS used by the participants were in fact quite limited. Strategies such as keeping word lists, checking meaning, etc. were not adequately exploited by the students. Even more generally, the participants remained largely inactive to the possibilities offered by SA contexts. According to Ife (2000: 34), students should be encouraged to use language learning strategies as these could provide them with opportunities for proactive language learning and working closely with the language.

A similar viewpoint is held by Adams (2006) who, in her study of nearly 90 SA participants from American universities, confirmed that the use of strategies has the potential to increase success in language acquisition. On the whole, in her study, the students participating in SA programmes did not differ significantly in linguistic gains from those learning a foreign language at home. However, those SA students who took advantage of strategies (particularly cognitive and metacognitive ones) were reported to have made significant gains over the course of a semester, particularly in improving their listening skills. However, it was noted that one's participation in a SA programme did not automatically mean one used language learning strategies. These findings seem to support the view that strategy-based instruction for SA students has the potential of maximising both linguistic and cultural gains. An additional finding of Adams' (2006: 268) study was that shorter stays abroad (i.e. less than four months) did not "challenge the students appreciably more than they are challenged in the classroom".

The effect of the context of learning (i.e. at home vs. study abroad) on communication strategies used by American learners of Spanish was investigated by Lafford (2004). Her results showed that SA participants used fewer communication strategies than learners in the "at home" group. According to the author, these results are not surprising as the expectations of (and towards) these two groups are different. Namely, the classroom counterparts were used to interacting with their teachers, whose role was to assist them and help them focus on the formal properties of the language. The participants of SA programmes interacted mostly with interlocutors in natural settings and the interlocutors were more interested in the message than in providing language instruction, or helping SA participants to express themselves.

On the basis of a large-scale interventionist study by Cohen et al. (2005) it can be reported that both language and culture learning strategy use correlates positively with gains in speech act performance and the development of intercultural sensitivity. The study involved students, study abroad professionals and language teachers. Its aim was to field test a series of teaching materials, 
including a self-study guidebook on language and culture learning strategies, designed at the University of Minnesota, which focused on maximising the outcomes of SA programmes. Part of the research project involved exploring language and culture learning strategies employed by students before, during and after their stay abroad. The group under investigation consisted of $86 \mathrm{stu}-$ dents, who spent a semester abroad studying either French or Spanish. While no significant differences were found between experimental and control groups, some variations were found on individual items. For instance, the experimental group developed five speaking and listening strategies as a result of their stay abroad. They also had higher scores on the use of generalisations versus stereotypes and on respecting communication styles. In particular, those students who scored higher on the listening strategy of paying attention to the interlocutor's tone of voice also improved on the Speech Act Measure of apology and request. Moreover, the use of the culture learning strategy of getting involved with host country members appeared to be correlated to improvements in pragmatic ability.

In two final studies of note, Kimura (2007 cited in Morita, 2010: 25) reports on the lasting effects of language learning strategies used by Japanese students after a short term SA programme in New Zealand. The strategies were used more by those who participated in the programme than those who did not and were used a month after they came back. Also, it was observed that Japanese participants preferred compensation, over memory, or affective strategies. Morita (2010: 31) reports similar conclusions: even a two-week stay abroad increased Japanese learners' use of language learning strategies and had a longer lasting effect. The preferred strategies were memory, cognitive, affective and social, whereas compensation and metacognitive strategies were widely used before and after the students' stay abroad.

\section{The study}

The present study is a response to a gap in current SLA research on SA programmes for learners of English as a foreign language. While literature of the field is abundant in reports on the development of language skills (e.g. Collentine, 2009; Kinginger, 2014) and intercultural competence of SA participants (Jackson, 2009; Róg, 2015; Watson and Wolfel, 2015), the study described below aims to track and examine changes over time to the various types of language and culture learning strategies employed by Polish students of English philology is SA contexts. In particular, the concept of intercultural communication in foreign language education requires more research evaluating the impact of immersion programmes on students' learning of culture, 
particularly with recourse to strategy-based instruction (Cohen et al., 2005: 36). This investigation may help us to understand which strategies are mostly employed by learners abroad and how their use changes while staying in a host culture, as well as to show which strategies are less popular or unfamiliar to learners. Training in these could potentially enhance the SA experience for the participants. The primary aims of this study are, first of all, to investigate which language and culture learning strategies were used by participants to cope with communication problems in study abroad contexts. The second aim is to track the potential changes in strategy use before and after the participants' stay abroad.

\subsection{Study design}

This study had a pre-test/post-test design in which participants completed questionnaires shortly before and shortly after their departures. Pre-visit data were collected between August and September 2015 and post-visit data in January 2016 from a group of 10 students participating in the Erasmus+ programme in Portugal and Romania. For the pre-test, the students completed the Strategies Inventory for Language Learning (SILL, Oxford, 1990) and Culture Learning Strategies Inventory (CLSI, Paige et al., 2002). Both these instruments are described further below. The participants agreed to take part in the study in personal conversation with the researcher at the end of July 2015 and the questionnaires were sent to them via e-mail in August 2015. For the post-test, the students also completed the SILL and a modified version of the CLSI (pre-departure strategies were omitted from this test as the students were already after their visits; the tense was changed into past), both of which were also sent electronically.

\begin{tabular}{|c|c|c|c|l|}
\hline & \multicolumn{1}{|c|}{ Sample } & Instrument & Date & Data analysis \\
\hline Pre-test & $\begin{array}{l}5 \text { (Adam Mickiewicz University in Poznań) } \\
+5 \text { (University of Applied Sciences in Piła) }\end{array}$ & SILL, CLSI & Aug-Sept 2015 & $\begin{array}{l}\text { Mean, SD, } \\
\text { frequency }\end{array}$ \\
\hline Post-test & $\begin{array}{l}5 \text { (Adam Mickiewicz University in Poznań) } \\
+5 \text { (University of Applied Sciences in Piła) }\end{array}$ & $\begin{array}{l}\text { SILL, modified } \\
\text { CLSI (see above) }\end{array}$ & January 2016 & $\begin{array}{l}\text { Mean, SD, } \\
\text { frequency }\end{array}$ \\
\hline
\end{tabular}

Table 1: Study design.

The sample for this study consisted of 10 second-year English philology students taking part in a semester-long Erasmus+ programme in Portugal and Romania. The students were majoring in English language education and applied linguistics at two higher education institutions (Adam Mickiewicz University in Poznań and University of Applied Sciences in Piła). They were 20-21 years old, of Polish origin, and with no experience of a prolonged stay abroad. There were three male and seven female students in the sample. All of them agreed voluntarily to take part in the study. They were also informed of their anonymity. 
The length of their stay abroad was on average 20 weeks (between September and January 2016). The study did not take into account the differences in strategy use across students immersed in different cultures.

\subsection{Tools}

The Strategies Inventory for Language Learning (SILL) is a widely-acknowledged research tool, whose various versions (e.g. SILL for English learners of other languages or SILL for speakers of other languages learning English) have been translated into numerous different languages. It is reported (Oxford, 2011: 159) that the SILL has now been used by over 10,000 language learners around the world and that the questionnaire has been utilised by the greatest number of descriptive studies (Chamot, 2004: 16). The second research tool, the Culture Learning Strategies Inventory (CLSI), is a tried and tested assessment method which, in order to be validated, was administered to a sample of University of Minnesota students. The data indicated a high reliability of the questionnaire (Cronbach alpha .72-.84).

\subsubsection{Strategies Inventory for Language Learning (SILL)}

Strategies Inventory for Language Learning is designed to test a learner's general strategy use and not to show a specific use of strategies in particular language tasks. Items in the SILL are largely based on Rebecca L. Oxford's taxonomy of strategies but they also include additional items adapted from early strategy research by O'Malley, Chamot and Rubin (Oxford, 1990: 255).

In the present study, a 50-item questionnaire for those learning English as a second/ foreign language was utilised (Version 7.0 ESL/EFL, Oxford, 1990: 293-298). Each item in the SILL is placed on a 5-point Likert-type scale with ratings between "never or almost never true of me" (1) and "always or almost always true of me" (5). The items are grouped into 6 categories (parts) A-F. These parts relate to different types of LLS, however, these types are not referred to directly. The types and sample items are as follows:

Part A: memory-related LLS, e.g. I use rhymes to remember new English words.

Part B: cognitive LLS, e.g. I say or write new English words several times.

Part C: compensatory LLS, e.g. to understand unfamiliar English words, I make guesses.

Part D: metacognitive LLS, e.g. I notice my English mistakes and use that information to help me do better.

Part E: affective LLS, e.g. I try to relax whenever I feel afraid of using English.

Part F: social LLS, e.g. I ask English speakers to correct me when I talk. 
In statistical tests the instrument's reliability and validity has been proven to be high across various cultural groups (Cronbach alpha .89-.90).

\subsubsection{Culture Learning Strategies Inventory (CLSI)}

The Culture Learning Strategies Inventory (CLSI) (Paige et al., 2002) was primarily designed as a self-assessment tool for University of Minnesota students participating in SA programmes. It contains a list of strategies which are comprehensive in terms of suggestions stemming from research, theory and experience (Paige et al., 2002: 175). It comprises 60 items placed on a 4-point Likert-type scale with poles being "This strategy does not suit me" (1) and "I use this strategy and I like it" (4). The aim of the CLSI is to find out about SA participants as culture learners and to discover those strategies which help them best adapt to new cultures. It asks the participants to reflect on what they do and what they might do in order to function effectively in a new culture. The strategies are divided into pre-departure, in-country and post-study abroad strategies. Each group is further subdivided. The types of strategies and sample items are as follows:

1. Strategies for when I am in surroundings that are culturally different from what I am used to, e.g. looking at similarities and differences among people of different backgrounds.

2. Strategies I will likely use to adjust to a new culture and cope with culture shock, e.g. Explain my cross-cultural experiences (the good and the difficult) to my family and friends at home.

3. Strategies for dealing with difficult times in the new culture, e.g. Keep in touch with friends and family back home by writing letters and emails.

4. Strategies for making judgments about another culture, e.g. Observe the behaviour of people from my host country very carefully.

5. Strategies for communicating with people from another culture, e.g. Don't assume that everyone from the same culture is the same.

6. Strategies to deal with different communication styles, e.g. Listen to whether my conversation partners are indirect or direct in their communication styles.

7. Strategies to understand nonverbal communication in another culture, e.g. Observe the gestures that people use in my host country.

8. Strategies to interact with people in the host culture, e.g. Join clubs or organisations to meet people who have interests like mine.

9. Strategies to use when I return home, e.g. Give myself time to readjust to my own country. 


\subsection{Study results}

The following section presents the results obtained in the course of the present study. It presents both pre- and post-test results focusing on strategies reported in both the SILL and the CLSI. It also points to the most and least used strategies.

\subsubsection{Pre-test results}

The six groups of language learning strategies were measured using the SILL for learners of English as a second/foreign language. 50 statements placed on a 5point Likert-type scale provided data for establishing a mean score for each of the six categories. In order to report the findings, Oxford (1990) suggested using scale ranges which explain the mostly used strategies in learning English: High Usage (5.0-3.5), Medium Usage (3.4-2.5), and Low Usage (2.4-1.0). As shown in Table 2, the lowest rank in the pre-test was given by the participants to affective strategies. The medium rank was awarded to memory and cognitive strategies, while the strategies most preferred among SA participants before their departures belonged to compensation and metacognitive categories.

\begin{tabular}{|c|c|c|c|c|c|c|}
\hline Variable & Mean & SD & $\begin{array}{c}\text { Minimum } \\
\text { (item number) }\end{array}$ & $\begin{array}{c}\text { Maximum } \\
\text { (item number) }\end{array}$ & Scale range & Difference \\
\hline Memory & 3.00 & 0.89 & $1.9(5,6)$ & $4.1(2)$ & Medium & \multirow{7}{*}{$\begin{array}{r}\text { Aff }<\text { Mem }<\text { Cog } \\
<\text { Soc; Com }<\text { Met }\end{array}$} \\
\hline Cognitive & 3.40 & 0.54 & $2.6(18)$ & $4.3(15)$ & Medium & \\
\hline Compensation & 3.58 & 0.64 & $2.9(28)$ & $4.6(29)$ & High & \\
\hline Metacognitive & 3.91 & 0.61 & $2.5(34)$ & $4.6(32)$ & High & \\
\hline Affective & 2.39 & 1.13 & $1.0(43)$ & $3.9(40)$ & Low & \\
\hline Social & 3.58 & 0.83 & $2.4(48)$ & $4.7(45)$ & High & \\
\hline Average & 3.32 & 0.77 & - & - & Medium & \\
\hline
\end{tabular}

Table 2: The SILL pre-test results.

\begin{tabular}{|l|c|l|c|}
\hline Strategy category & Strategy No. & \multicolumn{1}{|c|}{ Strategy statement } & Mean \\
\hline Social & 45 & $\begin{array}{l}\text { If I do not understand something in English, I ask the other } \\
\text { person to slow down or to say it again. }\end{array}$ & 4.7 \\
\hline Compensatory & 29 & $\begin{array}{l}\text { If I can't think of an English word, I use a word or phrase that } \\
\text { means the same thing. }\end{array}$ & 4.6 \\
\hline Metacognitive & 32 & I pay attention when someone is speaking English & 4.6 \\
\hline \multicolumn{4}{|l|}{} \\
\hline Memory & 5 & I use rhymes to remember new English words & 1.9 \\
\hline Affective & 41 & I give myself a reward or treat when I do well in English. & 1.5 \\
\hline Affective & 43 & I write down my feelings in a language learning diary. & 1.0 \\
\hline
\end{tabular}

Table 3: The pre-test SILL most and least reported strategies. 
Table 3 presents six individual strategies reported from the SILL, arranged in descending order with the three strategies most and three least used by the participants. The most used strategy was the social strategy no. $45(M=4.7)$, whereas least chosen was affective strategy no. 43 ( $M=1.0)$ (see Table 2).

In the pre-test, the studied group of Erasmus students chose metacognitive as their preferred strategies, while affective strategies were the least preferred of the six groups. Before their departure the participants appeared to favour strategies connected with planning and organising their learning.

The participants were also asked for an honest self-assessment of the 52 items placed on the CLSI, which uses four Likert-type responses ranging from 1 to 4 („This strategy is not for me" to "I like this strategy and will use it"). Similarly to the SILL, the CLSI groups statements into different categories (described above). In the analysis of the results, the mean for each group of strategies was been calculated. The data obtained in this part of the study can be found in Table 4.

\begin{tabular}{|c|c|c|c|c|c|}
\hline Variable & Mean & SD & $\begin{array}{c}\text { Minimum } \\
\text { (item number) }\end{array}$ & $\begin{array}{c}\text { Maximum } \\
\text { (item number) }\end{array}$ & Difference \\
\hline Pre-departure & 3.14 & 0.22 & $2.8(1)$ & $3.5(5)$ & \multirow{10}{*}{$\begin{array}{c}\text { Non }<\text { Dif }<\text { Int }<\text { Pre } \\
<\text { Pos }<\text { Com }<\text { ComS }<\text { Adj }<\text { Jud }\end{array}$} \\
\hline Adjusting & 3.40 & 0.48 & $2.6(11)$ & $3.9(9)$ & \\
\hline Difficulties & 3.06 & 0.96 & $1.4(15)$ & $3.9(14)$ & \\
\hline Judgments & 3.50 & 0.18 & $3.3(21)$ & $3.7(19)$ & \\
\hline Communicating & 3.26 & 0.83 & $1.8(25)$ & $3.8(26)$ & \\
\hline Comm. styles & 3.36 & 0.32 & $2.8(31)$ & $3.7(33)$ & \\
\hline Nonverbal & 3.01 & 0.41 & $2.3(35)$ & $3.6(40)$ & \\
\hline Interaction & 3.12 & 0.56 & $2.4(42)$ & $3.7(45)$ & \\
\hline Post-departure & 3.25 & 0.74 & $2.4(55,60)$ & $3.6(57,58)$ & \\
\hline Average & 3.23 & 0.52 & - & - & \\
\hline
\end{tabular}

Table 4: The CLSI pre-test results.

\begin{tabular}{|l|c|l|c|}
\hline \multicolumn{1}{|c|}{$\begin{array}{c}\text { Strategy } \\
\text { category }\end{array}$} & $\begin{array}{c}\text { Strategy } \\
\text { No. }\end{array}$ & \multicolumn{1}{|c|}{ Strategy statement } & Mean \\
\hline Adjusting & 9 & $\begin{array}{l}\text { I will consider what my friends living in the host country say about } \\
\text { people from my own culture, using what I know about cultural bias. }\end{array}$ & 3.9 \\
\hline Difficulties & 14 & $\begin{array}{l}\text { I will keep in touch with friends and family back home by writing } \\
\text { letters and emails. }\end{array}$ & 3.9 \\
\hline Communicating & 26 & $\begin{array}{l}\text { I will build relationships with local people by finding opportunities } \\
\text { to spend time with them. }\end{array}$ & 3.8 \\
\hline Non-verbal & 35 & $\begin{array}{l}\text { I will examine how my own nonverbal communication is influenced } \\
\text { by my culture. }\end{array}$ & 2.3 \\
\hline Communicating & 25 & $\begin{array}{l}\text { I will read local newspapers to better understand the current politi- } \\
\text { cal and social issues in my host country. }\end{array}$ & 1.8 \\
\hline Difficulties & 15 & I will keep a journal or a diary about my experiences. & 1.4 \\
\hline
\end{tabular}

Table 5: The pre-test CLSI most and least preferred strategies. 
As can be seen in Table 5, the participants reported the strategy of adjusting to a foreign culture (no.9, $M=3.9$ ) and the strategy of dealing with difficulties during their stay abroad (no. 14, $M=3.9$ ) as their preferred ones. The strategy of keeping a journal or a diary (no.15, $M=1.4$ ) appeared to be the least preferred.

\subsubsection{Post-test results}

At the end of their stay on the Erasmus programme, the participants were asked to complete the SILL survey again. As shown in Table 6, the lowest rank in the post-test was given by the participants to affective strategies. The medium rank was awarded to memory strategies, while the most preferred strategies among SA participants at the end of their departures were compensation, cognitive, social and metacognitive categories.

\begin{tabular}{|c|c|c|c|c|c|c|}
\hline Variable & Mean & SD & $\begin{array}{c}\text { Minimum } \\
\text { (item number) }\end{array}$ & $\begin{array}{c}\text { Maximum } \\
\text { (item number) }\end{array}$ & Scale range & Difference \\
\hline Memory & 2.89 & 0.87 & $1.375(6)$ & $4.12(2)$ & Medium & \multirow{7}{*}{$\begin{array}{c}\text { Aff }<\text { Mem }<\text { Com }< \\
\text { Cog }<\text { Soc }<\text { Met }\end{array}$} \\
\hline Cognitive & 3.68 & 0.64 & $2.5(19)$ & $4.37(15)$ & High & \\
\hline Compensation & 3.64 & 0.6 & $2.87(26)$ & $4.25(24)$ & High & \\
\hline Metacognitive & 3.8 & 0.77 & $2.12(34)$ & $4.62(30)$ & High & \\
\hline Affective & 2.39 & 1.30 & $1(43)$ & $4.25(40)$ & Low & \\
\hline Social & 3.72 & 1.31 & $2(46)$ & $4.62(47,49)$ & High & \\
\hline Average & 3.35 & 0.91 & - & - & Medium & \\
\hline
\end{tabular}

Table 6: The SILL post-test results.

Table 7 presents six individual strategies reported from the post-test SILL arranged in descending order with the three most and three least used by the participants.

\begin{tabular}{|l|c|l|c|}
\hline \multicolumn{1}{|c|}{ Strategy category } & Strategy No. & \multicolumn{1}{|c|}{ Strategy statement } & Mean \\
\hline Metacognitive & 30 & I try to find as many ways as I can to use my English. & 4.62 \\
\hline Social & 47 & I practice English with other students. & 4.62 \\
\hline Social & 49 & I ask questions in English. & 4.62 \\
\hline \multicolumn{4}{|l}{} \\
\hline Memory & 6 & I use flashcards to remember new English words. & 1.37 \\
\hline Affective & 41 & I give myself a reward or treat when I do well in English. & 1.25 \\
\hline Affective & 43 & I write down my feelings in a language learning diary. & 1 \\
\hline
\end{tabular}

Table 7: The post-test SILL most and least reported strategies.

The results of the post-test demonstrate a visible growth in the use of cognitive and social strategies during the participants' stay abroad. The affective strategies remained those least employed as they had been before the study abroad experience. 
The post-test results of the CLSI can be found in Table 8. As evidenced, the most preferred group of strategies were adjusting strategies $(M=3.58)$. At the other end of the scale, the participants indicated nonverbal strategies ( $M=$ 2.84 ) as the ones they employed least during their stay abroad.

\begin{tabular}{|c|c|c|c|c|c|}
\hline Variable & Mean & SD & $\begin{array}{c}\text { Minimum } \\
\text { (item number) }\end{array}$ & $\begin{array}{c}\text { Maximum } \\
\text { (item number) }\end{array}$ & Difference \\
\hline Adjusting & 3.58 & 1.34 & $2.75(12)$ & $3.87(8,9)$ & \multirow{9}{*}{$\begin{array}{r}\text { Non }<\text { Com }<\text { Dif }<\text { Post }< \\
\text { Int }<\text { ComS }<\text { Jud }<\text { Adj }\end{array}$} \\
\hline Difficulties & 3.02 & 1.24 & $1.25(15)$ & $4.0(14)$ & \\
\hline Judgments & 3.5 & 0.19 & $3.25(20)$ & $3.75(22)$ & \\
\hline Communicating & 2.87 & 1.00 & $1.75(25)$ & $4.0(26)$ & \\
\hline Comm. styles & 3.45 & 0.18 & $3.25(31,33)$ & $3.62(28,29,30)$ & \\
\hline Nonverbal & 2.84 & 0.42 & $2.25(36)$ & $3.37(34)$ & \\
\hline Interaction & 3.18 & 0.89 & $1.87(42)$ & $3.75(43,44)$ & \\
\hline Post-departure & 3.10 & 0.79 & $2.25(56)$ & $4.0(59)$ & \\
\hline Average & 3.19 & 0.75 & - & - & \\
\hline
\end{tabular}

Table 8: The CLSI post-test results.

Table 9 presents the most and the least preferred strategies used by SA participants during their stay. According to the results of the CLSI, strategies no. 14, 26 and 59 turned out to be the ones most often employed by the participants ( $M=4.0)$, whereas the least chosen strategy was no. $15(M=1.25)$.

\begin{tabular}{|c|c|c|c|}
\hline Strategy category & Strategy No. & Strategy statement & Mean \\
\hline Difficulties & 14 & $\begin{array}{l}\text { Keep in touch with friends and family back home by writing } \\
\text { letters and emails. }\end{array}$ & 4.0 \\
\hline Communicating & 26 & $\begin{array}{l}\text { Build relations with local people by finding opportunities to } \\
\text { spend time with them. }\end{array}$ & 4.0 \\
\hline Post-departure & 59 & $\begin{array}{l}\text { Try to stay connected with friends I made while studying } \\
\text { abroad. }\end{array}$ & 4.0 \\
\hline Interaction & 42 & $\begin{array}{l}\text { Join clubs or organizations to meet people who have interests } \\
\text { like mine. }\end{array}$ & 1.87 \\
\hline Communicating & 25 & $\begin{array}{l}\text { Read local newspapers to better understand the current po- } \\
\text { litical and social issues in my host country. }\end{array}$ & 1.75 \\
\hline Difficulties & 15 & Keep a journal or a diary about my experiences. & 1.25 \\
\hline
\end{tabular}

Table 9: The pre-test CLSI most and least preferred strategies.

Finally, Table 10 presents the changes in participants' strategy use in the course of their stay abroad. With regard to language learning strategies, it can be observed that the use of cognitive, social and compensation strategies increased, whereas the use of memory and metacognitive strategies dropped. The changes were, however, not very great. As far as culture learning strategies are concerned, a slight increase can be observed in the strategies of adjusting 
to new cultures, using various communication styles and interacting with a foreign culture. At the same time, the participants reported a slightly lower use of strategies for dealing with difficulties, communicating with a foreign culture, trying to understand non-verbal communication and strategies for readjusting to their home cultures.

\begin{tabular}{|l|c|c|c|}
\hline \multicolumn{1}{|c|}{ Strategy } & Pre-test & Post-test & $\Delta$ (difference) \\
\hline \multicolumn{3}{|c|}{ SILL } \\
\hline Memory & 3.00 & 2.89 & -0.11 \\
\hline Cognitive & 3.40 & 3.68 & +0.28 \\
\hline Compensation & 3.58 & 3.64 & +0.06 \\
\hline Metacognitive & 3.91 & 3.8 & -0.11 \\
\hline Affective & 2.39 & 2.39 & 0 \\
\hline Social & 3.58 & 3.72 & +0.14 \\
\hline \multicolumn{4}{|c|}{ CLSI } \\
\hline Adjusting & 3.40 & 3.58 & +0.18 \\
\hline Difficulties & 3.06 & 3.02 & -0.04 \\
\hline Judgments & 3.50 & 3.50 & 0 \\
\hline Communicating & 3.26 & 2.87 & -0.39 \\
\hline Comm. styles & 3.36 & 3.45 & +0.09 \\
\hline Nonverbal & 3.01 & 2.84 & -0.17 \\
\hline Interaction & 3.12 & 3.18 & +0.06 \\
\hline Post-departure & 3.25 & 3.10 & -0.15 \\
\hline
\end{tabular}

Table 10: Changes in language and culture learning strategies use reported over the course of SA experience.

\section{Conclusions}

On the whole, it can be observed that the use of both language and culture learning strategies did not change much before and after the participants' foreign visits. In other words, the experience of studying abroad for one term had little impact on the choice and use of various strategies for learning a foreign language and/or learning a foreign culture. Clearly, the mere fact of having field experience in another country is not enough to automatically implement language and/or culture learning strategies. Yet, the data obtained allows us to indicate the use of which of these strategies were sustained during the participants' stay abroad.

The standard deviation (pre-test=1.13, post-test=1.30) observed in the use of affective strategies in both the pre- and post-test indicates there is some diversity between the participants. Even though in statistical terms affective strategies were the ones least deployed, the standard deviation may indicate that the use of these strategies is a very individual matter. As these strategies are connected with managing emotions, it is very difficult to define 
them, but at the same time it is understandable why the diversities were noted. Every SA participant brings with them a fine-spun net of various attitudes, motivations, and values. Yet, the fact that affective language learning strategies were given the lowest rates might suggest that SA participants display generally positive attitudes to their SA experience and therefore need not employ strategies for dealing with negative emotions. On the other hand, some researchers claim that gaining better control over one's emotions is not an issue favoured by many learners (cf. Mystkowska-Wiertelak, 2008: 145; Pawlak, 2011: 47)

The participants of this study mostly used metacognitive strategies for language learning, both before and after their stay abroad. The high means (pre-test=3.91, post-test=3.8) for metacognitive strategies allow the claim that SA participants are on the whole aware language learners who pay attention to the strengths and weaknesses of their communicative competence. This finding is partially supported by the findings of a study by MystkowskaWiertelak (2008: 144), who confirmed that it is metacognitive strategies that are most often used by Polish high school learners. The high use of metacognitive strategies by SA participants can be seen as related to their high level of autonomy as language learners, which in turn was identified by DroździałSzelest (2004: 41) as being related to being able to take control of one's learning outside the formal education system. The low standard deviation (pretest $=0.61$, post-test $=0.77$ ) for metacognitive strategies also supports the finding that they were the ones used most consistently by the participants.

With regard to culture learning strategies, it can be observed that they were commonly used by SA students. In the pre-test, the strategies for making judgements about other cultures achieved both the highest mean (3.5) and the lowest standard deviation (0.18) which allows the claim that the participants were fairly unanimous when it comes to withholding judgements about other cultures. This is a very promising finding, indicating that SA participants have the potential for being successful intercultural communicators. To be more specific, before their SA programmes they refrained from making quick judgments and tried to analyse people's behaviours from various perspectives.

Yet, the highest-scoring statement on the CLSI pre-test, as well as the group of strategies most often employed on the post-test were strategies for adjusting to a new culture, where participants claimed they took cultural biases into account while considering what their foreign friends say about people from the participants' own cultures. At the same time, the lowest-ranking group of strategies on both the pre- and post-test was the use of nonverbal strategies. This finding may denote that the participants are either unaware of or do not consider the importance of aspects such as, for example, personal distance in human communication. Future research might address this issue in a more descriptive manner. 


\section{BIBLIOGRAPHY}

Adams, R. 2006. "Language learning strategies in the study abroad context". (in) Language Learners in Study Abroad Contexts. (eds. DuFon, M.A, and Churchill, E.). Clevedon: Multilingual Matters: 259-292.

Blyth, A. 2012. "Extensive listening vs. listening strategies: response to Siegel". ELT Journal 66/2: 236- 239.

Chamot, A. U. 2004. "Issues in language learning research and teaching". Electronic Journal of Foreign Language Teaching, 1: 14-26.

Cohen, A., and Shively, R. 2007. "Acquisition of requests and apologies in Spanish and French: Impact of study abroad and strategy-building intervention". Modern Language Journal 91: 189-221.

Cohen, A.D. and Macaro, E. 2007. Language Learner Strategies. Oxford: Oxford University Press.

Cohen, A.D., Paige, R.M., Shively, R.L., Emert, H. and Hoff, J. 2005. Maximising Study Abroad through Language and Culture Strategies: Research on Students, Study Abroad Program Professionals, and Language Instructors. Minneapolis: Centre for Advanced Research on Language Acquisition, University of Minnesota.

Collentine, J.G. 2009. "Study abroad research: Findings, implications and future directions". (in) The Handbook of Language Teaching. (eds. Long, M.H. and Catherine, C.J.). New York: Wiley: 218-233.

Cross, J. 2011. "Metacognitive instruction for helping less-skilled learners". ELT Journal, 65/4: 408- 416.

Droździał-Szelest, K. 2004. "Strategie uczenia się języka obcego: badania a rzeczywistość edukacyjna". (in) Autonomia w nauce języka obcego. (ed. Pawlak, M.). Poznań-Kalisz: Wydawnictwo UAM: 31-43.

Green, J., and Oxford, R. L. 1995. "A closer look at learning strategies, L2 proficiency, and gender". TESOL Quarterly, 29: 261-297.

Griffiths, C. 2008. "Strategies and good language learners". (in) Lessons from Good Language Learners (ed. Griffiths, C.). Cambridge: Cambridge University Press.

$\mathrm{Gu}, \mathrm{Y}$. 2010. "Advance review: A new book on teaching and researching language learning strategies". Unpublished review, Wellington University, New Zealand.

Ife, A. 2000. "Language learning and residence abroad: how self-directed are students?". Language Learning Journal, 22: 30-37.

Jackson, J. 2009. Language, Identity and Study Abroad. Sociocultural Perspective. London: Equinox.

Kinginger, C. 2014. "Introduction: Social and cultural aspects of language learning in study abroad". (in) Social and Cultural Aspects of Language Learning in Study Abroad (ed. Kinginger, C.). Amsterdam: John Benjamins, BV: 3-16. 
Lafford, B. 2004. "The effect of context of learning on the use of communication strategies by learners of Spanish as a second language". Studies in Second Language Acquisition, 26: 201-226.

Ma, A., Wong, R. M. H. and Lam, W. Y.K. 2015. "Profiling language and culture strategy use patterns of ESL student teachers in study abroad by using self-reported data". Pedagogy, Culture \& Society, 23: 107-131.

Morita, M. 2010. "How does a short term study abroad influence language learning strategies? The case of the Intercultural Communication Programme at Yamagata University". 23-36. retrieved from http://www-h. yamagata-u.ac.jp/wp-content/uploads/2014/09/nenpou7_02.pdf [date of access 25.08.2015].

Mystkowska-Wiertelak, A. 2008. "The use of grammar learning strategies among secondary school students". (in) Investigating English Language Learning and Teaching. (ed. Pawlak, M.). Poznań-Kalisz: Wydawnictwo UAM: 139-148.

Oxford, R.L. 1990. Language Learning Strategies. What Every Teacher Should Know. Boston, MA: Heinle \& Heinle.

Oxford, R.L. 2011. Teaching and Researching Language Learning Strategies. Harlow: Pearson Longman.

Oxford, R.L. and Ehrman, M. 1995. "Adults' language learning strategies in an intensive foreign language program in the United States". System, 23: 359-386.

Oxford, R.L. and Schramm, K. 2007. "Bridging the gap between psychological and sociocultural perspectives on $L 2$ learner strategies". (in) Language Learner Strategies. (eds. Cohen, A. D. and Macaro, E.). Oxford: Oxford University Press: 47-68.

Paige, R.M. Rong, J., Zhang, W., Kappler, B., Hoff, J. and Emert, H. 2002. Strategies Inventory for Learning Culture. Minneapolis, MN: Center for Advanced Research on Language Acquisition, University of Minnesota.

Pawlak, M. 2011. "Użycie strategii uczenia się gramatyki przez studentów filologii angielskiej". Neofilolog, 37: 39-54.

Pawlak, M. 2013. "Researching grammar learning strategies: Combining the macro- and microperspective". (in) Perspectives on Foreign Language Learning. (eds. Salski, Ł., Szubko-Sitarek, W. and Majer, J.). Łódź: Wydawnictwo Uniwersytetu Łódzkiego: 191-209.

Rost, M. and Wilson, J.J. 2013. Active Listening. London: Routledge.

Róg, T. 2015. "Preparing tertiary education students for study abroad programmes - the identity negotiation perspective". (in) Issues in Teaching, Learning and Testing Speaking in a Second Language. (eds. Pawlak, M. and Waniek-Klimczak, E.). Berlin-Heidelberg: Springer-Verlag: 69-84.

Swan, M. 2008. "Talking sense about learning strategies". RELC Journal, 43: 151-167. Thorn, S. 2013. "Debunking authentic listening". Modern English Teacher 21/2: 65-69. 
Language and culture learning strategies in a study abroad context

Watson, J. R., and Wolfel, R. 2015. "The intersection of language and culture in study abroad: Assessment and analysis of study abroad outcomes". Frontiers: The Interdisciplinary Journal of Study Abroad, XXV: 57-72. 